\title{
Non Hodgkin lymphoma in the maxillary sinus mimicking dental abscess: a case report
}

\author{
Ji-Young Song* \\ Department of Oral and Maxillofacial Surgery, School of Medicine, Jeju National University, Jeju, Republic of Korea
}

Malignant lymphomas are neoplasms with diffuse proliferation of neoplastic lymphocytes and their precursor cells. Diffuse large B-cell lymphoma, which is a subtype of non-Hodgkin's lymphomas, rarely occurs in the head and neck area and is especially rare in the maxillary sinus. We report a case of a 76-year-old female patient who was referred to the oral and maxillofacial surgery office for evaluation of a dental abscess as a clinical diagnosis. Laboratory tests revealed no signs of inflammation or infection; therefore, incisional biopsy was performed. The final diagnosis was diffuse large B-cell lymphoma in the maxillary sinus. Here we describe this case with a review of relevant literature. (J Dent Rehabil Appl Sci 2016;32(2):130-4)

Key words: maxillary sinus; non-hodgkin lymphoma; diffuse large B-cell lymphoma; dental abscess

\section{Introduction}

Malignant lymphomas are malignant neoplasms of the lympho-reticular system; they have an overall mortality rate of more than $55 \%{ }^{1-3}$ In the oral cavity, malignant lymphomas constitute about $5 \%$ of all lymphomas. The most frequently affected sites are the palate and Waldeyer's ring. Gingivae, floor of the mouth, paranasal sinuses, salivary glands, cheeks, and buccal sulcus are rarely affected. ${ }^{3-5}$

Malignant lymphomas are divided into two groups: Hodgkin's disease and non-Hodgkin's lymphomas (NHL). Diffuse large B-cell lymphoma (DLBCL), a subtype of NHL, rarely affects the head and neck area as primary lesion sites $(>1 \%) .^{1-3}$ DLBCL occurs predominantly in males from the $7^{\text {th }}$ decade of life and is characterized by a fast growing mass with symptoms. ${ }^{5-7}$ The etiology of DLBCL is not clearly

*Correspondence to: Ji-Young Song

Professor, Department of Oral and Maxillofacial Surgery, Jeju National University Hospital, 15, Aran 13-gil, Jeju-si, Jeju Special Self-Governing Province, 63241, Republic of Korea

Tel: +82-64-717-1845, Fax: +82-64-717-1102, E-mail: 2460song@naver.com

Received: April 29, 2016/Last Revision: June 13, 2016/Accepted: June 14, 2016 defined but it is thought to be caused by immunosuppression or a virus. ${ }^{5}$ Radiotherapy, chemotherapy, and concurrent chemoradiotherapy are possible treatment modalities for DLBCL. ${ }^{8}$

Here we report a case of primary DLBCL that mimicked a dental abscess and maxillary sinusitis.

\section{Case Report}

A 76-year-old female patient was referred to the oral and maxillofacial surgery office for evaluation of facial swelling in the right infraorbital region and gingival swelling in the right maxillary posterior area after functional endoscopic sinus surgery from the otorhinolaryngology office. She had endoscopic surgery twice during 2 months for previously diagnosed right maxillary sinusitis.

She had no history of smoking or alcohol abuse.

Copyright@ 2016 The Korean Academy of Stomatognathic Function and Occlusion. (c) This is an Open-Access article distributed under the terms of the Creative Commons Attribution Non-Commercial License (http://creativecommons.org/ licenses/by-nc/4.0) which permits unrestricted non-commercial use, distribution, and reproduction in any medium, provided the original work is properly cited. 
Medically, she had hypertension, diabetes mellitus, and osteoarthritis of the knee. She had dull pain during palpation and eating. There was no history of bleeding or discharge in the right maxillary region.

Extraoral examination detected swelling, redness, and heating sense in the right infraorbital area (Fig. 1). Intraoral examination detected a slightly elevated vestibular gingiva covered with intact mucosa without ulceration in the right maxillary posterior region. No exposure of necrotic bone was detected. In the dental panoramic view, no bony irregularity was found (Fig. 2). Computed tomography (CT) revealed a loss of bony continuity of the lateral wall and the upper wall (infraorbital region) of the right maxillary sinus (Fig. 3). Magnetic resonance imaging (MRI) revealed a mildly enhanced large mass in the right maxillary sinus and pterygopalatine fossa with an extension into the subperiosteal space of the right orbit. Bony destruction of the right zygoma, maxillary anterior and posterior walls, and the inferior orbital wall was detected. The size of the mass was approximately $5.4 \mathrm{~cm} \times 4.0 \mathrm{~cm} \times 4.0 \mathrm{~cm}($ length $\times$ width $\times$ height $)$



Fig. 1. Swelling and redness on the right infraorbital area was detected in the clinical photography.

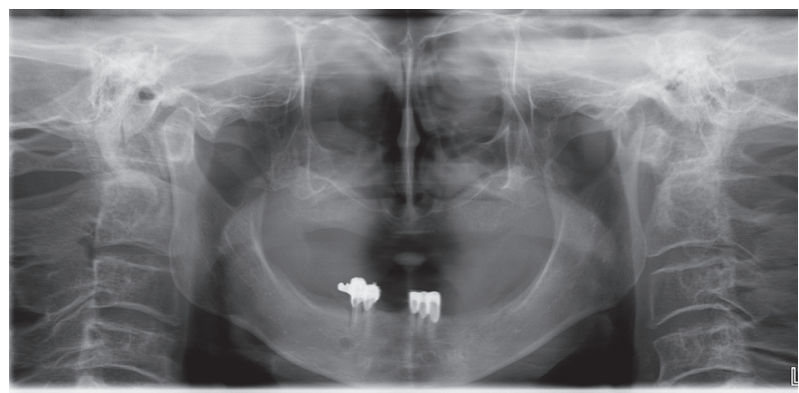

Fig. 2. In the dental panoramic view, no specific findings were detected.
(Fig. 4). Reactive enlarged lymph nodes were detected in the neck area. Positron emission tomography/ computed tomography (PET/CT) revealed a large hypermetabolic lesion in the right maxillary area and in the colon or small bowel, which was suspected to be a metastatic lesion (Fig. 5). In laboratory analysis,

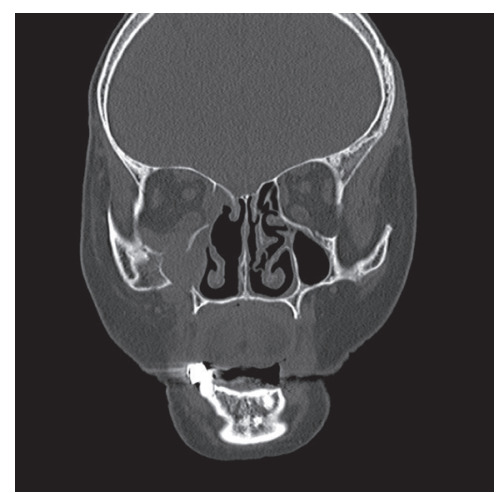

Fig. 3. Computed tomography (CT) revealed loss of bony continuity of lateral wall and upper wall of the right maxillary sinus.

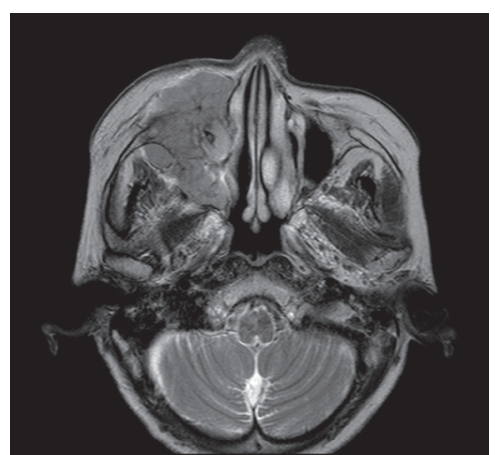

Fig. 4. In the magnetic resonance imaging (MRI) revealed mild enhancing large mass in the right maxillary sinus (T2 weighted axial image).

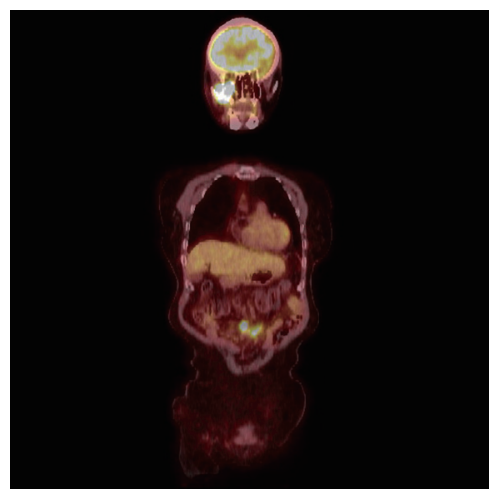

Fig. 5. A positron emission tomography/computed tomography (PET/CT) revealed large hypermetabolic lesion in the right maxillary area and in the colon or small bowel. 


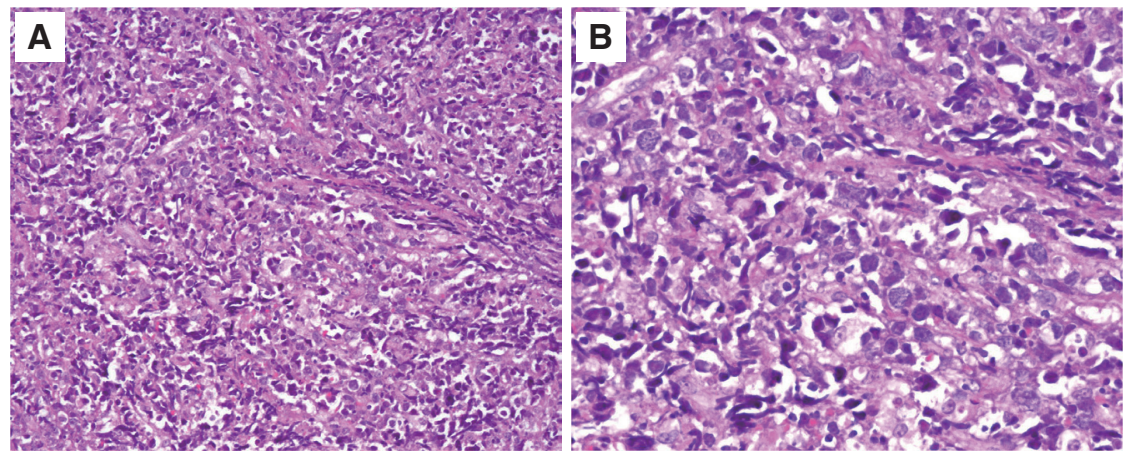

Fig. 6. The histological analysis revealed diffuse proliferation of large neoplastic B cell with large nuclei (Hematoxylin eosin staining, (A) $\times 200,(B) \times 400)$.
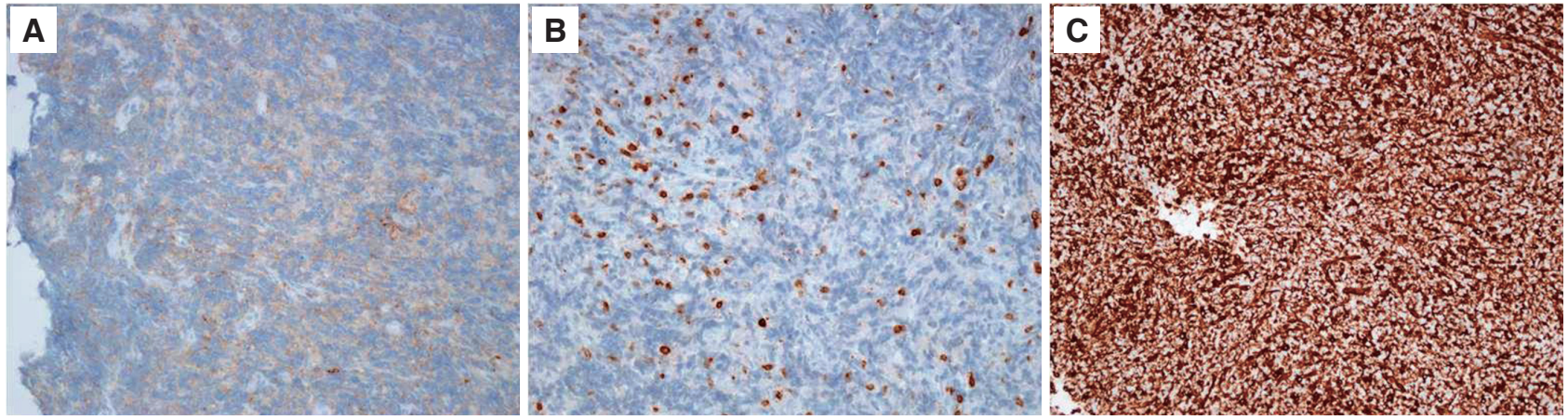

Fig. 7. The immunohistochemical staining $(\times 20,(A) C D 45,(B) C D 3$, (C) vimentin).

white blood cell count and high-sensitivity C-reactive protein were within the normal range. A slightly elevated level of blood sugar $(127 \mathrm{mg} / \mathrm{dL})$ was detected, which was due to diabetes mellitus.

Incisional biopsy was performed under local anesthesia. An incision was made in the vestibular sulcus in the right maxillary posterior region and mass was incised with adjacent normal tissue. Through the destroyed lateral wall of the right maxillary sinus, a small amount of the mass in the maxillary sinus was also incised. Histological analysis revealed DLBCL (Fig. 6, 7). According to our routine treatment proto$\mathrm{col}$, the patient was treated with concurrent chemoradiotherapy.

\section{Discussion}

NHL that occurs in the paranasal sinus constitutes $9-13 \%$ of all NHL cases and is predominantly Bcell lymphoma. It is rare and has poor prognosis because of delayed correct diagnosis, which is com- plicated by its non-specific symptoms. ${ }^{9}$

DLBCL is aggressive extranodal disease ( $>40 \%$ ) with fast tumor growth. ${ }^{10}$ Rhinosinusitis, pain, facial and mucosal swelling, nasal obstruction, fever, epistaxis, and weight loss are the main symptoms of paranasal DLBCL. ${ }^{11,12}$

In Western populations, lymphoma of the maxillary sinus is more prevalent than lymphoma of the nasal cavity. However, in Asian populations, the latter is more prevalent. ${ }^{3}$ In most cases of lymphoma of the paranasal sinus, CT examination reveals a large mass occupying the paranasal sinus. The best tool for radiologic diagnosis of a soft tumor extension is MRI. In MRI, a lymphoma has slightly elevated signal intensity and appears as a heterogeneous solid mass. ${ }^{12}$ PET/CT is also a helpful diagnostic imaging tool for lympho$\mathrm{ma}^{2}$ In our case, the mass showed high signal intensity and had a heterogeneous solid form in a T2 weighted image, and a high uptake signal was observed in the right maxillary sinus on a PET/CT image.

Histologically, DLBCL is characterized by diffuse 
proliferation of large neoplastic B-cells. The size of the nuclei is more than twice that of normal lymphocytes and is equal to or exceeds the size of normal macrophage nuclei. ${ }^{1,13} \mathrm{CD} 3, \mathrm{CD} 45 \mathrm{RO}, \mathrm{CD} 56$, and TIA-1 are the most important immunohistological diagnostic markers of lymphoma. ${ }^{14}$ In our case, histological analysis revealed diffuse proliferation of large neoplastic B cells with large nuclei; these cells were slightly positive for CD45 and CD3 and strongly positive for vimentin in immunohistological staining. Therefore, the tumor was diagnosed as DLBCL.

Although DLBCL of the maxillary sinus is rare, its differential diagnosis with some aggressive inflammatory or infectious diseases (such as invasive fungal sinusitis and dental abscesses) is necessary. ${ }^{12,13}$

The current treatment strategy for DLBCL is chemotherapy with multiple agents such as cyclophosphamide, prednisone, oncovin, and hydroxydoxorubicin, whereas surgical resection plays an extremely limited role. ${ }^{13}$

\section{Conclusion}

In conclusion, because of non-specific symptoms, diagnosis of the early stages of DLBCL is often delayed. Misdiagnosis of an early stage of DLBCL in the maxillary sinus as maxillary sinusitis or a dental abscess is frequent. Therefore, surgical biopsy may be necessary for the final diagnosis together with using radiologic tools, such as CT, MRI, and PET/CT.

\section{References}

1. Bhattacharyya I, Chehal HK, Cohen DM, Al-Quran SZ. Primary diffuse large B-cell lymphoma of the oral cavity: germinal center classification. Head Neck Pathol 2010;4:181-91.

2. Aral CA, Ağlarcı OS, Yılmaz HH, Taşlı F, Karaarslan S, Hatipoğlu F, Sanal MS. Diagnosis, PET/ CT imaging, and treatment of extranodal nonHodgkin lymphoma in keratinized gingiva: a case report. J Oral Sci 2015;57:59-62.

3. Chalastras T, Elefteriadou A, Giotakis J, Soulandikas K, Korres S, Ferekidis E, Kandiloros D. Non-Hodgkin's lymphoma of nasal cavity and paranasal sinus- es. A clinicopathological and immunohistochemical study. Acta Otorhinolaryngol Ital 2007;27:6-9.

4. Angiero F, Stegani M, Crippa R. Primary nonHodgkin's lymphoma of the mandibular gingiva with maxillary gingival recurrence. Oral Oncol Ext 2006;42:123-8.

5. Adwani DG, Arora RS, Bhattacharya A, Bhagat B. Non-Hodgkin's lymphoma of maxillary sinus: an unusual presentation. Ann Maxillofac Surg 2013;3:95-7.

6. Alacacioglu I, Ozcan MA, Ozkal S, Piskin O, Turgut N, Demirkan F, Ozsan GH, Kargi A, Undar B. Prognostic significance of immunohistochemical classification of diffuse large B-cell lymphoma. Hematology 2009;14:84-9.

7. Kolokotronis A, Konstantinou N, Christakis I, Papadimitriou P, Matiakis A, Zaraboukas T, Antoniades D. Localized B-cell non-Hodgkin's lymphoma of oral cavity and maxillofacial region: a clinical study. Oral Surg Oral Med Oral Pathol Oral Radiol Endod 2005;99:303-10.

8. Coiffier B. State-of-the-art therapeutics: diffuse large B-cell lymphoma. J Clin Oncol 2005;23:6387-93.

9. Tinoco P, Pereira JC, Ferreira FR, Carrara VL, Tinoco MB. B-cell non-Hodgkin lymphoma of the ethmoid sinus. Braz J Otorhinolaryngol 2013;79: 259.

10. Neves MC, Lessa MM, Voegels RL, Butugan O. Primary non-Hodgkin's lymphoma of the frontal sinus: case report and review of the literature. Ear Nose Throat J 2005;84:47-51.

11. Ferry JA, Sklar J, Zukerberg LR, Harris NL. Nasal lymphoma. A clinicopathologic study with immunophenotypic and genotypic analysis. Am J Surg Pathol 1991;15:268-79.

12. Yasumoto M, Taura S, Shibuya H, Honda M. Primary malignant lymphoma of the maxillary sinus: CT and MRI. Neuroradiology 2000;42:285-9.

13. Kumar G, Hingad N, Singh N, Sidhu GK. Diffuse large B - Cell lymphoma involving the maxilla in a minor. J Clin Diagn Res 2014;8:ZD26-8.

14. Drénou B, Lamy T, Amiot L, Fardel O, CauletMaugendre S, Sasportes M, Diebold J, Le Prisé PY, Fauchet R. CD3- CD56+ non-Hodgkin's lymphomas with an aggressive behavior related to multidrug resistance. Blood 1997;89:2966-74. 


\section{치성 농양과 유사한 상악동에 발생한 비호지킨 림프종의 증례 보고}

\section{송지영*}

제주대학교 의학전문대학원 의학과 치과

악성 림프종은 림프 세포와 그들의 전구 세포에 광범위한 증식이 발생하는 종양으로 비호지킨 림프종과 호지킨 림프종 으로 크게 나뉠 수 있다. 미만성 큰 B세포 림프종은 비호지킨 림프종에 속하는 림프종으로 구강악안면 영역에서 극히 적은 빈도로 발생한다. 또한 이는 비특이적 증상, 예를 들면 안면부 부종, 통증, 발열 및 체중 감소 등을 가지며 따라서 구강악안면 부위의 다른 염증성 및 감염성 질환과 감별 진단이 매우 중요하다.

(구강회복응용과학지 2016;32(2):130-4)

주요어: 상악동; 치성 농양; 비호지킨 림프종; 미만성 큰 B세포 림프종 